\title{
Comparison of Creatinine, Cystatin, CKD-EPI Cystatin C, CKD-EPI Creatinine and MDRD equations in estimating glomerular filtration rate in patients with nephrotic syndrome
}

\section{Nefrotik sendromlu hastalarda glomerüll filtrasyon hızI tahmininde creatinin, sistatin, CKD-EPI cystatin C, CKD- EPI creatinine ve MDRD formüllerinin karşılaştırılması}

\author{
Sibel Yüicel Koçak, Arzu Özdemirr
}

Department of Nephrology, University of Health Sciences, Bakirkoy Dr. Sadi Konuk Education and Research Hospital, Istanbul,Turkey Corresponding author: Sibel Yücel Koçak, MD, Department of Nephrology, University of Health Sciences, Bakirkoy Dr. Sadi Konuk Education and Research Hospital, Istanbul,Turkey

E-mail: fsibelkocak@yahoo.com

Received/Accepted: April 07, 2021 /May 19, 2021

Conflict of interest: There is not a conflict of interest.

\section{SUMMARY}

Objective: It's recommended to use equations such as Modification of Diet in Renal Disease (MDRD) and Chronic Kidney Disease Epidemiology Collaboration (CKD-EPI) by using creatinine level in estimating glomerular filtration rate (GFR). Here, we aimed to compare serum cystatin-C (Cys-C) and Cys- $\mathrm{C}$ based equations with creatinine and creatinine based equations in patients with chronic kidney disease (CKD) and nephrotic syndrome (NS).

Method: A total of 142 patients with CKD (30 with NS and 112 without NS) followed in the nephrology outpatient clinic were included into the study. The patients were divided into two groups as NS $(n=30)$ and non-NS $(\mathrm{n}=112)$.

Results: Out of 142 patients, $74(52.1 \%)$ were male. Mean age of the patients was $51.94 \pm 14.23$ years $(17-80)$. There was no significant difference in terms of age, gender and diabetes prevalence rates between the patients with NS and non-NS ( $p>0.05$ ). Proteinuria was $6300.77 \pm 3192.47$ grams in the NS group and $1112.09 \pm 1004.36$ grams in the non-NS group $(p=0.001)$. Total cholesterol and LDL values were found to be significantly higher in patients with $\mathrm{NS}$ ( $\mathrm{p}=0.033$ and $\mathrm{p}=0.017$, respectively). While there was no difference in serum creatinine level between the two groups, the Cys-C value in the NS group was found to be significantly higher than those of non-NS group $(2.44 \pm 0.94$ vs $2.00 \pm 0.99 ; \mathrm{p}=0.014)$. CKD-EPI-CysC GFR and CKD-EPI Cr-CysC values were found to be significantly lower in the NS group than in the non-NS group ( $\mathrm{p}=0.025, \mathrm{p}=0.042$, respectively). No significant difference was found between the two groups in CKD-EPI$\mathrm{Cr}, \mathrm{MDRD}$ formula and creatinine clearance.

Conclusions: Formulas based on alternative markers such as Cys-C may be more advantageous for the correct estimation of GFR. In this study, we showed that CKD-EPI-CysC and CKD-EPI Cr-CysC are better in detecting CKD than others in the evaluation of renal functions in NS.
Sibel Yücel Koçak

Arzu Özdemir

ORCID IDs of the authors: S.Y.K. 0000-0003-3984-4043 A.Ö. 0000-0001-7651-7282 
Keywords: Cystatin-C, chronic kidney disease epidemiology collaboration, glomerular filtration rate, nephrotic syndrome

\section{ÖZET}

Amaç: Glomerüler filtrasyon hızını (GFH) tahmin etmede kan kreatinin düzeyi kullanılarak Böbrek Hastalığında Diyet Modifikasyonu (MDRD) ve Kronik Böbrek Hastalığı Epidemiyoloji işbirliği (CKD-EPI) gibi denklemlerin kullanılması önerilmektedir. Burada kronik böbrek hastalığı ve nefrotik sendromu (NS) olan hastalarda serum Cys-C ve Cys-C bazlı denklemleri kreatinin ve kreatinin bazlı denklemlerle karșılaștırmayı amaçladık.

Yöntem: Çalışmaya nefroloji polikliniğine başvuran kronik böbrek hastalığı olan 30nefrotik sendromlu ve 112 nefrotik sendromu olmayan toplam 142 hasta dahil edildi.

Bulgular: 142 hastanın 52.1'i (n=74) erkekti. Yaş ortalamaları $51.94 \pm 14.23$ yıl (17-80) idi. NS varlığına göre olguların yaş, cinsiyet ve diyabet görülme oranları açısından anlamlı bir fark yoktu ( $\mathrm{p}>0.05)$. Nefrotik sendromlu hastalarda total kolesterol ve LDL değerleri anlamlı olarak yüksek bulundu ( $\mathrm{p}=0.033$; $\mathrm{p}=0.017)$. Proteinüri NS grubunda $6300.77 \pm$ 3192.47 gram, non-NS grubunda $1112.09 \pm 1004.36$ gramdı $(p=0.001)$. Serum kreatinin düzeyi açısından 2 grup arasında fark yokken, NS grubundaki Cys-C değeri non-NS grubuna göre istatistiksel olarak anlamlı yüksek bulundu (2.44 \pm 0.94 ; $2.00 \pm 0.99 ; \mathrm{p}=0.014, \mathrm{p}<0.05)$. NS grubunda CKD-EPI-CysC GFH ve CKD-EPI-Cr-CysC değeri non-NS grubuna göre anlamlı olarak daha düşük saptandı ( $\mathrm{p}=0.025, \mathrm{p}=0.042$, sırasıyla). CKD-EPI-Cr, MDRD formülü ve kreatinin klirensi açısından iki grup arasında anlamlı bir fark saptanmadı.

Sonuç: Cys-C gibi alternatif belirteçlere dayalı formüller, GFR'nin doğru tahmini için daha avantajlı olabilir. Bu çalıșmada NS'de böbrek fonksiyonlarının değerlendirilmesinde CKD-EPI-CysC ve CKD-EPICr-CysC'nin kronik böbrek hastalığını tespit etmede diğerlerine göre daha iyi olduğunu gösterdik.

Anahtar sözcükler: Sistatin-C, kronik böbrek hastalığı epidemiyoloji iş birliği, glomerüler filtrasyon hızı, nefrotik sendrom

\section{INTRODUCTION}

Glomerular filtration rate (GFR) is a commonly used index for evaluating renal function, especially for the diagnosis, staging, and prognostic evaluation of chronic kidney disease (CKD). Inulin clearance, 51Cr-EDTA, 99m Tc-DTPA and iohexol are accepted as the gold standard for GFR measurement. However, it is not widely used due to its application difficulty and high cost ${ }^{1}$. Serum creatinine is the most widely used endogenous GFR marker. However, it is affected by muscle mass, age, gender, race, ethnicity, and chronic diseases. In addition, as the tubular secretion of creatinine increases when renal function decreases, the clearance measured with creatinine increases in these patients ${ }^{2}$. Therefore, equations based on serum creatinine and cystatin $\mathrm{C}(\mathrm{Cys}-\mathrm{C})$ levels have been developed in the evaluation of renal functions. The Modification of Diet in Renal Disease (MDRD) equation and the Chronic Kidney Disease Epidemiology Collaboration (CKD-EPI) equation (provided by the Kidney Disease: Improving Global Outcomes (KDIGO) clinical practice guidelines in 2012) are the most reliable equations ${ }^{3-5}$. MDRD predicts GFR better than other equations for early CKD patients. CKD-EPI has greater precision and is preferred when estimating GFR for classification of CKD stage and GFR $>60 \mathrm{ml} / \mathrm{min} / 1.73 \mathrm{~m} 2{ }^{6-8}$. The KDIGO 2012 guidelines recommended use of creatininebased GFR estimating equation and creatinine- cystatin $\mathrm{C}$ based GFR estimating equations to derive $\mathrm{GFR}^{6}$.

Cys-C is a low molecular weight $(13 \mathrm{kDa})$ protein and a cysteine proteinase inhibitor. It has been proposed as a new endogenous marker of GFR. Cys-C is freely filtered through the glomerulus, reabsorbed and metabolized but not secreted by the proximal tubule. Serum Cys-C concentration appears to be independent of muscular mass, gender, age, nutritional status and chronic diseases. It is recommended as a more precise marker than creatinine in estimating GFR, especially in individuals with mild kidney injury ${ }^{9}$ and in some clinical conditions such as hepatic cirrhosis, diabetes mellitus, kidney transplant recipients and in the elderly ${ }^{10-13}$. However, studies in specific groups such as nephrotic syndrome (NS) are insufficient. This study was aimed to compare Cys$\mathrm{C}$, creatinine, MDRD formula (simplified), CKDEPI-Cr (creatinine-based CKD-EPI equation), CKD-EPI-CysC (cystatin C-based CKD-EPI equation), CKD-EPICr-CysC (CKD-EPI equation for eGFR, based on both serum creatinine and serum Cys-C), creatinine clerance (CrCL) between patients with NS and those without NS.

\section{MATERIAL AND METHODS}

This retrospective study included 142 patients $(68$ females, 74 males) with CKD regularly followed up and treated in nephrology outpatient clinics of Bakirkoy Dr. Sadi Konuk Education and Research 
Hospital between January, 2014 and October, 2016. The patients were divided into two groups as NS $(\mathrm{n}=30)$ and non-NS $(\mathrm{n}=112)$. NS was defined as 24$\mathrm{h}$ urine protein $>3.5 \mathrm{~g} /$ day, low serum albumin, high serum cholesterol, and peripheral edema. Written informed consents were not obtained due to the retrospective design of the study. Approval was obtained from the hospital clinical research ethics committee (2016/200, 27.07.2016).

Fasting blood glucose, creatinine, cystatin-C, albumin, total cholesterol and triglyceride values of all patients were recorded from electronic health system of our hospital. Creatinine, creatinine clearance, proteinuria and microalbuminuria levels were evaluated simultaneously in 24-hour urine.

Abbott-Aeroset Autoanalyzer original kit was used to measure biochemical parameters (AbbottAeroset System, Germany). Creatinine clearance, proteinuria and microalbuminuria levels were evaluated by using Beckman Coulter preanalytical and modulator system and photometric method (UniCel Dxc 800, USA). Serum Cys-C levels were measured by Immunassay method (The Detectx Cys-C Immunassay Kits, Arbor Assays, United States). The normal range of serum Cys-C levels was $0.48-0.98 \mathrm{mg} / \mathrm{L}$ in the adult; $0.93-3.35 \mathrm{mg} / \mathrm{dL}$ in elderly (over 65 years old). The normal range of serum creatinine was $0.5-0.9 \mathrm{mg} / \mathrm{dL}$.

Patients using flucytosine, trimethoprim sulfamethoxazole, cephalosporin were not included in the study as they may affect renal functions and creatinine values. Since microalbuminuria and proteinuria levels could be measured incorrectly, patients with hemoglobin A1c above $8 \%$, and presenting with acute and chronic inflammation (upper and lower respiratory tract infections, urinary tract infection, diabetic foot infection) were excluded from the study. Patients were prohibited from exercising excessively and eating a low-high protein diet before collecting 24-hour urine to measure proteinuria appropiately. Body weights were measured using the same device. Patients were divided into 3 subgroups of CKD according to eGFR as follows: Stage 1: GFR $\geq 90 \mathrm{~mL} / \mathrm{min} / 1.73$ $\mathrm{m}^{2}$, Stage 2: GFR $=60-89 \mathrm{~mL} / \mathrm{min} / 1.73 \mathrm{~m}^{2}$, Stage 3: GFR $\leq 59 \mathrm{~mL} / \mathrm{min} / 1.73 \mathrm{~m}^{2}$.

In calculating creatinine clearance: "Urine creatinine $X$ 24-hour urine volume / Serum creatinine / 1440" formula was used.

Estimated GFR (eGFR) was calculated by MDRD equation. eGFR also was calculated by the new CKD-EPI equations using Scr, Cys-C or both.
MDRD study equation is: $186 \mathrm{X}$ Serum creatinine ${ }^{1.154}$ X Age (years) ${ }^{-0.203}$ X Gender X Ethnic formula

CKD-EPI creatinine $(\mathrm{Cr})$ equation is: $141 \mathrm{x}$ min $(\mathrm{Scr} / \mathrm{\kappa}, 1)^{\alpha} \times \max (\mathrm{Scr} / \mathrm{\kappa}, 1)^{-1.209} \times 0.993^{\mathrm{Age}} \times 1.018$ (if female) $x 1.159$ (if black)

$[\kappa=0.7$ if female $; \kappa=0.9$ if female; $\alpha=-0.329$ if female ; $\alpha=-0.411$ if male;

$\min =$ The minumum of $\mathrm{Scr} / \mathrm{\kappa}$ or 1 ;

$\max =$ The maximum of Scr/K or 1;

$\mathrm{Scr}=$ serum creatinine $(\mathrm{mg} / \mathrm{dl})$

CKD-EPI-CysC equation is: $\mathrm{eGFR}=127.7 \times$ $\mathrm{CysC}^{-1.17} \times \mathrm{age}^{-0.13} \times(0.91$ if female $)$

CKD-EPI Cr-CysC equation is: $\mathrm{eGFR}=177.6 \times$ $\mathrm{Scr}^{-0.65} \times \mathrm{CysC}^{-0.57} \times$ age $^{-0.20} \times(0.82$ if female $)$

\section{Statistical Analysis}

NCSS (Number Cruncher Statistical System) program was used for statistical analysis. Descriptive statistical methods (Mean, standard deviation, median, frequency, percentage, minimum, maximum) were used while evaluating the study data. The suitability of quantitative data to normal distribution was tested by Shapiro-Wilk test and graphical analysis. Student-t test was used for comparisons of normally distributed quantitative variables between two groups and Mann-Whitney U test was used for comparisons of quantitative variables that did not show normal distribution between two groups. Pearson chisquare test and Fisher-Freeman-Halton exact test were used to compare qualitative data. Statistical significance was accepted as $\mathrm{p}<0.05$.

\section{RESULTS}

A total of 142 patients, $47.9 \%(\mathrm{n}=68)$ female and $52.1 \%(\mathrm{n}=74)$ male, were included in the study. Their mean age was $51.94 \pm 14.23$ years (17-80). Patients were divided into 2 groups as non-NS $(n=112)$ and NS $(n=30)$. There was no significant difference in terms of age, gender and diabetes prevalence rates of the patients according to the presence of NS ( $>0.05)$ (Table 1). Primary renal diseases in NS group were diabetic nephropathy $(n=12)$, membranous nephropathy $(n=10)$, primary focal segmental glomerulosclerosis $(n=3)$, amyloidosis $(n=3)$, minimal change disease $(n=1)$ and the others $(\mathrm{n}=1)$. When the microalbuminuria and protein levels of both groups were compared, a significant difference was found. Proteinuria was found to be $6300.77 \pm 3192.47$ grams in NS group and $1112.09 \pm 1004.36$ grams in NNS group $(\mathrm{p}=0.001)$ (Table 2). Cholesterol and LDL values were found to be significantly higher in patients with NS ( $p=0.033 ; p=0.017$, respectively). 
Table 1: Demographic characteristics of the patients

\begin{tabular}{|l|l|l|l|l|l|}
\hline \multicolumn{2}{|c|}{} & Total & NS $(\mathrm{n}=30)$ & Non-NS $(\mathrm{n}=112)$ & $\mathrm{p}$ \\
\hline Age (years) & Median(Q1-Q3) & $50(17-80)$ & $51.5(20-80)$ & $56(17-73)$ & 0.087 \\
\cline { 2 - 6 } & Mean \pm SD & $51.94 \pm 14.23$ & $48.00 \pm 14.17$ & $53.00 \pm 14.12$ & \\
\hline Sex & Female & $68(47.9)$ & $14(46.7)$ & $54(48.2)$ & \\
\cline { 2 - 6 } & Male & $74(52.1)$ & $16(53.3)$ & $58(51.8)$ & \\
\hline $\begin{array}{l}\text { Diabetes } \\
\text { mellitus }\end{array}$ & Yes & $44(31.2)$ & $12(40.0)$ & $32(28.8)$ & \\
\cline { 2 - 6 } & No & $97(68.8)$ & $18(60.0)$ & $79(71.2)$ & \\
\hline
\end{tabular}

Abbreviations: NS: nephrotic syndrome; non-NS: non-nephrotic syndrome; Q1-Q3: interquartile range, ${ }^{\text {a Student-t }}$ Test, ${ }^{b}$ Pearson Chi-Square Test

Table 2: Comparison of laboratory data between NS (nephrotic syndrome) and non-NS (non-nephrotic syndrome) groups.

\begin{tabular}{|c|c|c|c|c|c|}
\hline & & Total & NS $(n=30)$ & Non-NS ( $\mathrm{n}=112)$ & $\mathrm{p}$ \\
\hline \multirow{2}{*}{$\begin{array}{l}\text { Total cholesterol } \\
(\mathrm{mg} / \mathrm{dL})\end{array}$} & Median(Q1-Q3) & $209(119-540)$ & $227.5(141-540)$ & $200.5(119-357)$ & c $0.033^{*}$ \\
\hline & Mean \pm SD & $212.13 \pm 56.64$ & $238.43 \pm 81.48$ & $205.09 \pm 45.86$ & \\
\hline \multirow{2}{*}{$\begin{array}{l}\text { LDL-cholesterol } \\
(\mathrm{mg} / \mathrm{dL})\end{array}$} & Median(Q1-Q3) & $127(49-436)$ & $142(75-436)$ & $123.5(49-242)$ & ${ }^{\mathrm{c}} 0.017 *$ \\
\hline & Mean \pm SD & $132.04 \pm 48.17$ & $157.14 \pm 71.63$ & $125.54 \pm 37.75$ & \\
\hline \multirow[t]{2}{*}{ Triglyceride (mg/dL } & Median(Q1-Q3) & $154.5(37-504)$ & $187.5(91-504)$ & $147.5(37-451)$ & ${ }^{\mathrm{c}} 0.064$ \\
\hline & Mean \pm SD & $178.97 \pm 92.17$ & $205.03 \pm 98.46$ & $171.99 \pm 89.58$ & \\
\hline 24-h urine albümin & Median(Q1-Q3) & 689(0-8700) & $3100(133-8700)$ & $400(0-2300)$ & ${ }^{\circ} 0.001 * *$ \\
\hline (mg/day) & Mean \pm SD & $1323.37 \pm 1701$. & $3808.8 \pm 2027.59$ & $657.63 \pm 696.18$ & \\
\hline 24-h urine protein & Median(Q1-Q3) & $1200(42-17168)$ & $5227(3500-17168)$ & $749(42-3300)$ & $0.001 * *$ \\
\hline (mg/day) & Mean \pm SD & $2208.29 \pm 2721$ & $6300.77 \pm 3192.47$ & $1112.09 \pm 1004.36$ & \\
\hline
\end{tabular}

Abbreviations: LDL-cholesterol: Low density lipoprotein- cholesterol; NS: nephrotic syndrome; non-NS: (nonnephrotic syndrome): Q1-Q3: interquartile range, ${ }^{c}$ Mann Whitney U Test ${ }^{*} \mathrm{p}<0.05 * * \mathrm{p}<0.01$

Serum creatinine value of cases without NS was found to be lower compared to those of NS group, it didn't reach statistical significance $(\mathrm{p}=0.054)$. However, the Cys-C value in the NS group was significantly higher than non-NS group (2.44 \pm $0.94 ; 2.00 \pm 0.99$; respectively, $p=0.014)$. GFR measured by serum creatinine, serum Cys-C, CKDEPI-Cr, CKD-EPI-CysC, CKD-EPI-Cr+CysC, MDRD formula (simplified) and $\mathrm{CrCL}$ were compared between the groups. There was no significant difference between CKD stages of the
NS patients according to CKD-EPI-Cr, CKD-EPICysC, CKD-EPI-Cr+CysC, MDRD, CrCL $(\mathrm{p}>0.05)$ formula. When using the CrCL formula, more patients were grouped as stage $1 \quad(n=34$, $23.9 \%$ ) but it didn't reach statistical significance. The distribution of the patients according to CKD stages is shown in Table 3. CKD-EPI-CysC and CKD-EPI-Cr + CysC value were significantly lower in the NS group compared to the non-NS group $(\mathrm{p}=0.025$, and $\mathrm{p}=0.042$, respectively). 
Table3: Comparison of equation between NS (nephrotic syndrome) and non-NS (non-nephrotic syndrome) groups among CKD stages

\begin{tabular}{|c|c|c|c|c|c|}
\hline \multirow{3}{*}{ Creatinine } & & Total & NS $(n=30)$ & Non-NS (n=112) & $\mathrm{p}$ \\
\hline & Median(Q1-Q3) & $1.9(0.5-7.6)$ & $2.7(0.5-5.7)$ & $1.7(0.7-7.6)$ & c 0.054 \\
\hline & Mean \pm SD & $2.32 \pm 1.58$ & $2.72 \pm 1.47$ & $2.21 \pm 1.6$ & \\
\hline \multirow[t]{2}{*}{ Cystatin C } & Median(Q1-Q3) & $2(0.5-5.7)$ & $2.4(0.8-4.6)$ & $1.9(0.5-5.7)$ & ${ }^{\circ} 0.014 *$ \\
\hline & Mean \pm SD & $2.09 \pm 0.99$ & $2.44 \pm 0.94$ & $2.00 \pm 0.99$ & \\
\hline \multirow[t]{2}{*}{ CKD-EPI-Cr } & Median(Q1-Q3) & $37(7-141)$ & $25(9-141)$ & $38.5(7-132)$ & ${ }^{\circ} 0.096$ \\
\hline & Mean \pm SD & $47.75 \pm 35.93$ & $39.6 \pm 37.19$ & $49.94 \pm 35.44$ & \\
\hline \multirow[t]{3}{*}{ CKD-EPI-Cr } & Stage 1 & $27(19.0)$ & $4(13.3)$ & $23(20.5)$ & $\mathrm{b} 0.380$ \\
\hline & Stage 2 & $16(11.3)$ & $2(6.7)$ & $14(12.5)$ & \\
\hline & $\geq$ Stage 3 & $99(69.7)$ & $24(80.0)$ & $75(67.0)$ & \\
\hline \multirow[t]{2}{*}{ CKD-EPI-CysC } & Median(Q1-Q3) & $30(8-148)$ & $25(11-125)$ & $32(8-148)$ & ${ }^{c} 0.025^{*}$ \\
\hline & Mean \pm SD & $43.77 \pm 33.73$ & $33.67 \pm 27.44$ & $46.47 \pm 34.83$ & \\
\hline \multirow[t]{3}{*}{ CKD-EPI-CysC } & Stage 1 & $23(16.2)$ & $3(10.0)$ & $20(17.9)$ & ${ }^{\mathrm{d}} 0.383$ \\
\hline & Stage 2 & $11(7.7)$ & $1(3.3)$ & $10(8.9)$ & \\
\hline & $\geq$ Stage 3 & $108(76.1)$ & $26(86.7)$ & $82(73.2)$ & \\
\hline \multirow[t]{2}{*}{ CKD-EPICr-CysC } & Median(Q1-Q3) & $32.5(7-140)$ & $23.5(10-140)$ & $34(7-133)$ & ${ }^{\circ} 0.042 *$ \\
\hline & Mean \pm SD & $44.69 \pm 34.63$ & $35.2 \pm 32.14$ & $47.23 \pm 34.97$ & \\
\hline \multirow[t]{3}{*}{ CKD-EPICr-CysC } & Stage 1 & $23(16.2)$ & $3(10.0)$ & $20(17.9)$ & d 0.569 \\
\hline & Stage 2 & $13(9.2)$ & $2(6.7)$ & $11(9.8)$ & \\
\hline & $\geq$ Stage 3 & $106(74.6)$ & $25(83.3)$ & $81(72.3)$ & \\
\hline \multirow[t]{2}{*}{ MDRD } & Median(Q1-Q3) & $34.5(7-142)$ & $23.5(9-142)$ & $37(7-137)$ & ${ }^{\circ} 0.066$ \\
\hline & Mean \pm SD & $44.54 \pm 32.96$ & $37.73 \pm 36.41$ & $46.37 \pm 31.9$ & \\
\hline \multirow[t]{3}{*}{ MDRD } & Stage 1 & $17(12.0)$ & $4(13.3)$ & $13(11.6)$ & d 0.416 \\
\hline & Stage 2 & $21(14.8)$ & $2(6.7)$ & $19(17.0)$ & \\
\hline & $\geq$ Stage 3 & $104(73.2)$ & $24(80.0)$ & $80(71.4)$ & \\
\hline \multirow[t]{2}{*}{$\mathrm{CrCL}$} & Median(Q1-Q3) & $43.5(5-208)$ & $29(8-142)$ & $46(5-208)$ & ${ }^{\circ} 0.072$ \\
\hline & Mean \pm SD & $56.63 \pm 43.24$ & $44.67 \pm 37.98$ & $59.83 \pm 44.15$ & \\
\hline \multirow[t]{3}{*}{$\mathrm{CrCL}$} & Stage 1 & $34(23.9)$ & $5(16.7)$ & $29(25.9)$ & $\mathrm{b} 0.191$ \\
\hline & Stage 2 & $19(13.4)$ & $2(6.7)$ & $17(15.2)$ & \\
\hline & $\geq$ Stage 3 & $89(62.7)$ & $23(76.7)$ & $66(58.9)$ & \\
\hline
\end{tabular}

Abbreviations: CKD-EPI-Cr: creatinine-based CKD-EPI equation; CKD-EPI-CysC: cystatin C-based CKDEPI equation; CKD-EPICr-CysC: CKD-EPI equation for eGFR, based on both serum creatinine and serum cystatin C; MDRD; Modification of Diet in Renal Disease; CrCL: creatinine clearance, Q1-Q3: interquartile range, ${ }^{b}$ Pearson Chi-Square Test, ${ }^{c}$ Mann Whitney U Test, ${ }^{\mathrm{d}}$ Fisher Freeman Halton Test; ${ }^{*} \mathrm{p}<0.05$

\section{DISCUSSION}

Level of serum creatinine vary with age, gender, race, obesity, underlying chronic diseases (hypertension, DM) and remain within the normal range until significant renal function loss develops. Since, serum creatinine is not sufficient alone to determine and stage the kidney diseases, numerous GFR estimating equations are developed using combination of serum creatinine with demographic and clinical variables (age, sex, race, and body size). MDRD formula is one of the most frequently used formula to measure GFR. Recently CKD-EPI was recommended as a more accurate estimator of
GFR, especially for relatively higher GFR levels $(>60 \mathrm{ml} / \mathrm{min} / 1.73 \mathrm{~m} 2)^{14}$. Particularly, KDIGO and Kidney Disease Outcomes Quality Initiative (KDOQI) recommend use of these two equations to estimate $\mathrm{GFR}^{15}$.

Interpretation of GFR can be influenced by varying test characteristics in selected clinical circumstances and pre-existing disease. KDIGO consider newly developed equations based on standardized measurements of Cys-C for confirmatory testing in special conditions when eGFR based on serum creatinine is less accurate(e.g., extremes of muscle mass or diet), or 
when decisions depend on more accurate knowledge of GFR, such as confirming a diagnosis of CKD, determining eligibility for kidney donation, or adjusting dosage of nephrotoxic drugs 7. Also, NICE (National Institute for Health and Care) recommended to use eGFRCr-Cys $\mathrm{C}$ for confirmation of CKD ${ }^{16}$. In a study where CKDEPI creatinine was compared with CKD-EPI-Cr + $\mathrm{CysC}$, it was shown that more accurate results could be obtained with CKD-EPI-Cr + CysC, especially in patients $>70 \mathrm{ml} / \mathrm{min} / 1.73 \mathrm{~m} 2{ }^{17}$. Also, it was shown that cystatin-based equations and combined creatinine- Cys-C equations correlate better with Tc-99m DTPA even when GFR $<60$ $\mathrm{mL} / \mathrm{min} .{ }^{18}$.

Previous studies have shown that Cys-C detects kidney dysfuntion earlier than serum creatinine in proteinüric diabetic cases ${ }^{19}$. For this reason, it is recommended that Cys-C shoul be used for early diagnosis of renal dysfunction, especially in diseases that are expected to progress to chronic kidney failure, such as diabetic nephropathy.

The urinary excretion rate of Cys-C may reflect the early change in tubular function and GFR while the clearance rate of $\mathrm{Cr}$ is normal. As the GFR decreases, the urinary excretion of Cys-C and fractional excretion (FE) of Cys-C increases ${ }^{20}$. There are studies showing that urinary Cys-C is affected by proteinuria but it is unclear how proteinuria affects Cys-C. Urinary Cys-C excretion increases in patients with proteinuria ${ }^{21}$. The effect of this on GFR calculated by Cys-C is unknown. In this study, estimate GFR calculated by the serum Cys-C and Cys-C based equations in patients with proteinuria was lower than those of creatinine based equations.

Also, we evaluated the effect of massive proteinuria on CKD staging and found that serum creatinine remained at a normal level despite the decrease in GFR in NS. Therefore, serum creatinine values is not sufficient alone to evaluate the frequency and stages of kidney disease in patients with proteinuria. It is well known that endogenous creatinine clearance (ECC) in human overestimates GFR as a result of renal tubular secretion of creatinine. If there is a decrease in GFR, the contribution of tubular secretion to total creatinine excretion increases and consequently the overestimation of GFR by ECC will become more pronounced in patients with impaired renal function. It has been suggested that the tubular creatinine process also changes in patients with NS. Sodium reabsorption from the proximal tubule is reduced in patients with NS and severe hypoalbuminemia. Therefore, as a passive process, creatinine reabsorption will be affected by changes in water and sodium reabsorption. Serum albumin levels also affect tubular creatinine secretion ${ }^{20}$. As a result, GFR in NS is more significantly overestimated using endogenous creatinine clearance and modified MDRD equation. For these reasons, normal serum creatinine should not be seen as evidence of a normal GFR in patients with NS 22. Similarly, Hofstra et al showed that the MDRD formula underestimated GFR in patients with NS since hypoalbuminemia in patients with NS was associated with loss of urine albumin and not associated with malnutrition. Also, they have reported that serum albumin was negatively correlated with Cys-C ${ }^{23}$.

In our study, we used creatinine-based and cystatinbased eGFR formulas in NS (CKD-EPI-Cr, CKDEPI-CysC, CKD-EPI-CysC-Cr) and aimed to show the difference in kidney function tests When patients with NS and without NS were compared, there was no difference between serum creatinine and creatinine based eGFR formulas. However, significantly higher Cys-C level and lower CKDEPI-CysC and CKD-EPI Cr-CysC were detected in NS group. Our study demonstrated that only Cys$\mathrm{C}$ and Cys-C based formulas differed between NS and non-NS groups.

As mentioned before, level of serum creatinine vary with obesity and pre-existing disease. Obese patients have a higher GFR as they have less muscle mass and lower serum creatinine levels. Therefore, using serum Cys-C based equations may reflect the "true" GFR in obese patients ${ }^{24}$. Also, higher values of GFR have been found with CKD-EPI creatinine in cancer patients ${ }^{25}$.

In daily clinical practice, formulas to estimate GFR in patients with NS are limited. Since the study was conducted on a small number of patients, larger studies are needed.

In conclusion, serum creatinine and eGFR $\mathrm{Cr}$ should be the first test for evaluating kidney function. In CKD, the etiology of the disease and drugs of the patients may affect the results of renal function tests. For this reason, it may be more meaningful to evaluate renal function tests by taking into account disease etiology and treatments applied, apart from many parameters such as age, gender, race, and BMI. We observed that serum Cys-C and CKD-EPI-CysC formulas define CKD at an early stage in NS. It seems more appropriate to use cystatin C, CKD-EPI-CysC and CKD-EPI$\mathrm{Cr}+\mathrm{Cys} \mathrm{C}$ in special patients groups in order to prevent possible complications.

Conflict of Interests: The authors declare that they have no conflict of interest. 
Financial Disclosure: The author declared that this study received no financial support.

Acknowledgements: We thank Emire Bor, EMPIAR Statistics, for performing statistical analysis of the study.

\section{REFERENCES}

1. White CA, Akbari A, Allen $\mathrm{C}$, et al. Simultaneous glomerular filtration rate determination using inulin, iohexol, and 99mTc-DTPA demonstrates the need for customized measurement protocols. Kidney Int 2021;99(4), 957-966.https://doi. org/10.1016/ j.kint.2020.06.044

2. Lamb EJ, Stevens PE. Estimating and measuring glomerular filtration rate: methods of measurement and markers for estimation. Curr Opin Nephrol Hypertens 2014; 23(3): 258-266. https://doi: 10.1097/01.mnh.0000444813.72626.88.

3. Levey AS, Coresh J, Greene T, et al. Using standardized serum creatinine values in the modification of diet in renal disease study equation for estimating glomerular filtration rate. Ann Intern Med 2006;145(4): 247-254. https://doi:10.7326 /0003-4819-145-4200608150-00004.

4. Levey AS, Coresh J, Greene $\mathrm{T}$, et al. Expressing the Modification of Diet in Renal Disease Study equation for estimating glomerular filtration rate with standardized serum creatinine values. Clin Chem 2007;53 (4):766-772. https://doi: 10.1373/clinchem. 2006.077180 .

5. Ognibene A, Grandi $\mathrm{G}$, Lorubbio $\mathrm{M}$, et al. KDIGO 2012 Clinical Practice Guideline CKD classification rules out creatinine clearance 24hour urine collection? Clin Biochem 2016 ;49(1-2):85-89. 10.1016/j.clinbiochem. 2015.07.030.

6. Levin A, Stevens PE. Summary of KDIGO 2012 CKD Guideline: behind the scenes, need for guidance, and a framework for moving forward. Kidney Int 2014; 85(1):49-61. https://doi: 10.1038/ki.2013.444.

7. Levey AS, Becker C, Inker LA. Glomerular filtration rate and albuminuria for detection and staging of acute and chronic kidney disease in adults: a systematic review. JAMA 2015; 313(8): $\quad$ 837-846. https://doi: 10.1001/jama.2015.0602.

8. EarleyA, Miskulin D, Lamb EJ, Levey A S, Uhlig K. Estimating equations for glomerular filtration rate in the era of creatinine standardization: a systematic review. Ann Intern Med 2012;156 (11): 785-795. https://doi: $\quad 10.7326 / 0003-4819-156-6-$ 201203200-00391.

9. Shardlow A, McIntyre NJ, Fraser SDS, et al. The clinical utility and cost impact of cystatin $\mathrm{C}$ measurement in the diagnosis and management of chronic kidney disease: A primary care cohort study. PLoS Med. 2017;14(10): e1002400. https://doi: 10.1371/journal. pmed. 1002400.

10. Rosenblatt R, Verna EC. Cystatin C: The answer or a call for better kidney biomarkers in cirrhosis? Transplantation 2020; 104(7): e186e187. https://doi: 10.1097/TP.

0000000000003223.

11. Elsayed MS, El Badawy A, Ahmed A, Omar R, Mohamed A. Serum cystatin $C$ as an indicator for early detection of diabetic nephropathy in type 2 diabetes mellitus. Diabetes Metab Syndr. 2019;13(1):374-381. https://doi: 10.1016/j.dsx.2018.08.017.

12. Harman G, Akbari A, Hiremath S, et al. Accuracy of cystatin C-based estimates of glomerular filtration rate in kidney transplant recipients: a systematic review. Nephrol Dial Transplant 2013;28(3):741-757. https://doi: $10.1093 / \mathrm{ndt} / \mathrm{gfs} 498$.

13. Iacomelli I, Giordano A, Rivasi G, et al. Low Creatinine Potentially Overestimates Glomerular Filtration Rate in Older Fracture Patients: A Plea for an Extensive Use of Cystatin C? Eur J Intern Med 2020;25: S09536205(20)30254-5. https://doi: 1011016/j.ejim.2020.06.016.

14. Matsushita K, Mahmoodi BK, Woodward M, et al. Comparison of risk prediction using the CKD-EPI equation and the MDRD study equation for estimated glomerular filtration rate. JAMA 2012; 9;307(18):1941-1951. https://doi: 10.1001/jama.2012.3954.

15. Stevens PE, Levin A; Kidney Disease: Improving Global Outcomes Chronic Kidney Disease Guideline Development Work Group Members. Evaluation and management of chronic kidney disease: synopsis of the kidney disease: improving global outcomes 2012 clinical practice guideline. Ann Intern Med. 2013;4;158(11):825-830. https://doi: 10.7326/ 0003-4819-158-11-201306040-00007.

16. Carville S, Wonderling D, Stevens P; Guideline Development Group. Early 
identification and management of chronic kidney disease in adults: summary of updated NICE guidance. BMJ 2014; 24; 349: g4507. https://doi.org/10.1136/bmj.g4507.

17. Fan L, Inker LA, Rossert J, Froissart M, Rossing $\mathrm{P}$ et al. Glomerular filtration rate estimation using cystatin $\mathrm{C}$ alone or combined with creatinine as a confirmatory test. Nephrol Dial Transplant 2014 ;29(6):1195-1203. https:// doi: 10.1093/ndt/gft509.

18. Trimarchi H, Muryan A, Toscano A, et al. Proteinuria, (99m) Tc-DTPA Scintigraphy, Creatinine-, Cystatin- and Combined-Based Equations in the Assessment of Chronic Kidney Disease. ISRN Nephrol 2014;11; 2014:430247. https://doi: $10.1155 / 2014 / 430247$.

19. Perkins BA, Ficociello LH, Ostrander BE, et al. Microalbuminuria and the risk for early progressive renal function decline in type 1 diabetes. J Am Soc Nephrol 2007;18(4):13531361. https://doi: 10.1681/ASN.2006080872.

20. Kim JS, Kim MK, Lee JY, et al. The effects of proteinuria on urinary cystatin-C and glomerular filtration rate calculated by serum cystatin-C. Ren Fail 2012;34(6):676-684. https://doi: 10.3109/0886022X.2012.672154.
21. Tkaczyk M, Nowicki M, Lukamowicz J. Increased cystatin $\mathrm{C}$ concentration in urine of nephrotic children. Pediatr Nephrol 2004;19(11):1278-1280. https://doi: 10.1007/s00467-004-1566-1.

22. Branten AJ, Vervoort G, Wetzels JF. Serum creatinine is a poor marker of GFR in nephrotic syndrome. Nephrol Dial Transplant 2005;20(4):707-711. https://doi: 10.1093/ $\mathrm{ndt} / \mathrm{gfh} 719$.

23. Hofstra JM, Willems JL, Wetzels JF. Estimated glomerular filtration rate in the nephrotic syndrome. Nephrol Dial Transplant 2011;26(2):550-6. https://doi: 10.1093 /ndt/gfq443.

24. Alaje AK, Adedeji TA, Adedoyin AR, Idogun SE. Creatinine and cystatin C-based evaluation of renal function among obese subjects in Benin City, Nigeria. Saudi J Kidney Dis Transpl. 2019;30(3):648-654. https://doi: 10.4103/1319-2442.261339.PMID: 31249229.

25. Ciin MN, Proungvitaya T, Limpaiboon T, et al. Serum Cystatin C as a Potential Marker for Glomerular Filtration Rate in Patients with Cholangiocarcinoma. Int $\mathrm{J}$ Hematol Oncol Stem Cell Res. 2020;14(3):157-166. https://doi:10.18502/ijhoscr.v14i3.3723. 